\title{
Simultaneous Removal of Inorganic and Organic Pollutants from Polycontaminated Wastewaters on Modified Hemp-Based Felts
}

\author{
GRÉGORIO CRINI ${ }^{1 *}$, CORINA BRADU ${ }^{1,2}$, CESARE COSENTINO $^{1,3}$, \\ JEAN-NÖEL STAELENS ${ }^{4}$, BERNARD MARTEL ${ }^{4}$, MARC FOURMENTIN ${ }^{5}$, \\ SONIA LOIACONO ${ }^{1}$, GILLES CHANET ${ }^{6}$, GIANGIACOMO TORRI ${ }^{3}$, NADIA MORIN-CRINI ${ }^{1}$ \\ ${ }^{1}$ Chrono-environnement UMR 6249, Faculté Sciences et Techniques, Université Bourgogne Franche-Comté, 16 route de \\ Gray, 25000 Besançon, France \\ ${ }^{2}$ University of Bucharest, PROTMED Research Centre, 050663 Bucharest, Romania \\ ${ }^{3}$ Istituto di Chimica e Biochimica G. Ronzoni, 81 via G. Colombo, 20133, Milano, Italy \\ ${ }^{4}$ UMET UMR 8207, Ingénierie des Systèmes Polymères, Université de Lille, 59655 Villeneuve d'Ascq, France \\ ${ }^{5}$ Laboratoire de Physico-chimie de l'Atmosphère, EA 4493, Université du Littoral Côte-d'Opale, 59140, Dunkerque, France \\ ${ }^{6}$ Eurochanvre, 7 route de Dijon, 70100 Arc-les-Gray, France
}

\begin{abstract}
In this study, an adsorption process using hemp-based materials in felt form was applied to remove between 45 and 53 contaminants present in wastewater from the surface treatment industry. Several materials were compared using batch experiments, including a felt made of 100\% hemp fiber (HEMP), the same felt cross-linked with 1,2,3,4-butanetetracarboxylic acid (HEMPBA), a felt coated with a maltodextrin-1,2,3,4-butanetetracarboxylic cross-linked polymer (HEMPM), and a felt coated with hydroxypropyl- $\beta$-cyclodextrin-1,2,3,4-butanetetracarboxylic cross-linked polymer (HEMPCD). Chemical analysis showed that HEMPBA, HEMPM and HEMPCD materials had high adsorption capacities on metals in wastewater, confirming the role of carboxylic groups. Only HEMPCD was able to remove both metals and organics, resulting in the virtual elimination of organics such as chloroform, 1,2-dichlorobenzene, and nonylphenol. This result demonstrated the important role of cyclodextrin molecules in adsorption mechanism. HEMPCD also resulted in an important decrease in residual chemical oxygen demand and total organic carbon of more than $83 \%$ and $53 \%$, respectively, while the treatment with HEMP lowered them by $12 \%$ and $12 \%$, HEMPBA by $9 \%$ and $7 \%$, and HEMPM by $45 \%$ and $26 \%$. Chemical abatement and toxicity mitigation have demonstrated that adsorption onto a nonconventional material could be an interesting treatment step for the detoxification of wastewater.
\end{abstract}

Keywords: hemp, pollutants, wastewater, adsorption, batch experiments, cyclodextrin

\section{Introduction}

The European policy on water pollution results from the Water Framework Directive (WFD, Directive 2000/60/EC) of 2000, which established guidelines for the protection of surface water, underground water and coastal water in Europe. One of the objectives is to achieve good chemical and ecological status of all water bodies in Europe, before a deadline set for 2021 [1]. The WFD also classified chemicals into two main lists of priority substances (Directive 2006/11/EC). The first concerns particularly dangerous substances such as mercury, anthracene, 4-p-nonylphenol, pentachlorophenol and trichloromethane, substances considered to be highly toxic, persistent and bioaccumulative. The second includes priority substances such as trichlorobenzene, octylphenols, dichloromethane, lead and nickel, which are considered less toxic than those of the first list, but nevertheless present a significant risk to the environment. The surface treatment industry is particularly affected by many of these substances [1$3]$. Since the 2000s, Europe is asking industry to innovate to reduce and/or to eliminate chemicals present in their waters, i.e. wastewaters and discharge waters. Although considerable efforts have been made by the industry in general, and surface treatment industry in particular, over the last 20 years, the problem of water pollution remains a significant concern. So, the industrial sector continues to look into new treatment methods to decrease the levels of pollution present in their wastewaters $[1,4,5]$.

*email: gregorio.crini@univ-fcomte.fr 
The recent literature reports a multitude of low-cost, readily available and effective non-conventional agricultural and forestry materials for the treatment of contaminated waters, such as coir, jute, date pits, corncob, fruit peel waste, sawdust and bark [6-13]. Hemp-based materials have also been proposed for the removal of metals, mainly present in synthetic aqueous solutions [14-31]. The Romanian group of Păduraru [14-18], the Serbian group of Kostić [18-20] and the French group of Crini [25-31] are particularly active in this field. Our group recently published the first comprehensive review on metal sequestration by hemp-based adsorbents [30].

In previous works [27,28,31], we first proposed the use of a hemp material in felt form to treat metals present in synthetic polymetallic aqueous solutions and in discharge waters containing a mixture of metals. These discharges contained a relatively low contaminant load, but complied with regulations. Continuing our interest in these materials, we have presented here the results of analytical and ecotoxicological monitoring of wastewaters from a surface treatment industry containing a high contaminant load before and after hemp treatment using raw and modified materials. The two main objectives were to determine the ability of the materials to treat high contaminant loads and to highlight the role of the structure of the material in its performance in removing organic and inorganic contaminants. Four hemp-based materials were compared using batch experiments, a felt made of $100 \%$ hemp fiber, the same felt cross-linked with 1,2,3,4-butanetetracarboxylic acid, a felt coated with a maltodextrin-1,2,3,4-butanetetracarboxylic cross-linked polymer, and a felt coated with hydroxypropyl$\beta$-cyclodextrin-1,2,3,4-butanetetracarboxylic cross-linked polymer [26-29,31]. The chemical modification was made to provide ion-exchange properties to the material by introducing carboxylic groups [32-34]. First, a chemical and ecotoxicological analysis of three wastewaters was performed. Thirteen standard water parameters and over 170 substances including 33 metals, 58 volatile organic compounds (VOCs), 16 polycyclic aromatic compounds (PAHs), 24 chlorophenols (CPs), 16 alkylphenols (APs), 5 chloroanilines (CAs), 7 polychlorobiphenyls (PCBs), and 4 organo-tin complexes were monitored. Two ecotoxicological tests, namely measurements of inhibition of Daphnia magna mobility and germination rate of Lactuca sativa seeds, were also carried out on wastewaters. Then, we compared the performance of the four materials in the removal of the contaminants present in industrial effluents. This article presents the abatements obtained in chemical pollution and the impact on water toxicity before and after hemp treatment.

\section{Materials and methods}

\subsection{Hemp-based materials}

Hemp was kindly provided by Eurochanvre, a hemp processing company in Franche-Comté (Arcles-Gray, Haute-Saône, France). This material, noted HEMP, is a felt made of $100 \%$ hemp fiber. Before chemical modification, HEMP was extensively washed with osmosed water and then dried at $60^{\circ} \mathrm{C}$ until constant weight. Three modified materials were synthetized in order to provide ion-exchange properties to the HEMP material by introducing carboxylic groups through a cross-linking reaction with 1,2,3,4butanetetracarboxylic acid (BTCA) in absence or in presence of maltodextrin (MALTO, Glucidex® D19 from Roquette, Lestrem, France) or of hydroxypropyl- $\beta$-cyclodextrin (HP $\beta C D$ from Roquette, Lestrem, France). Chemical structures are reported in Scheme 1. The process and associated chemical pathway to produce a felt cross-linked with 1,2,3,4-butanetetracarboxylic acid (HEMPBA), a felt coated with a maltodextrin-1,2,3,4-butanetetracarboxylic cross-linked polymer (HEMPM), and a felt coated with hydroxypropyl- $\beta$-cyclodextrin-1,2,3,4-butanetetracarboxylic cross-linked polymer (HEMPCD) have been detailed elsewhere [26,27,30-34]. 


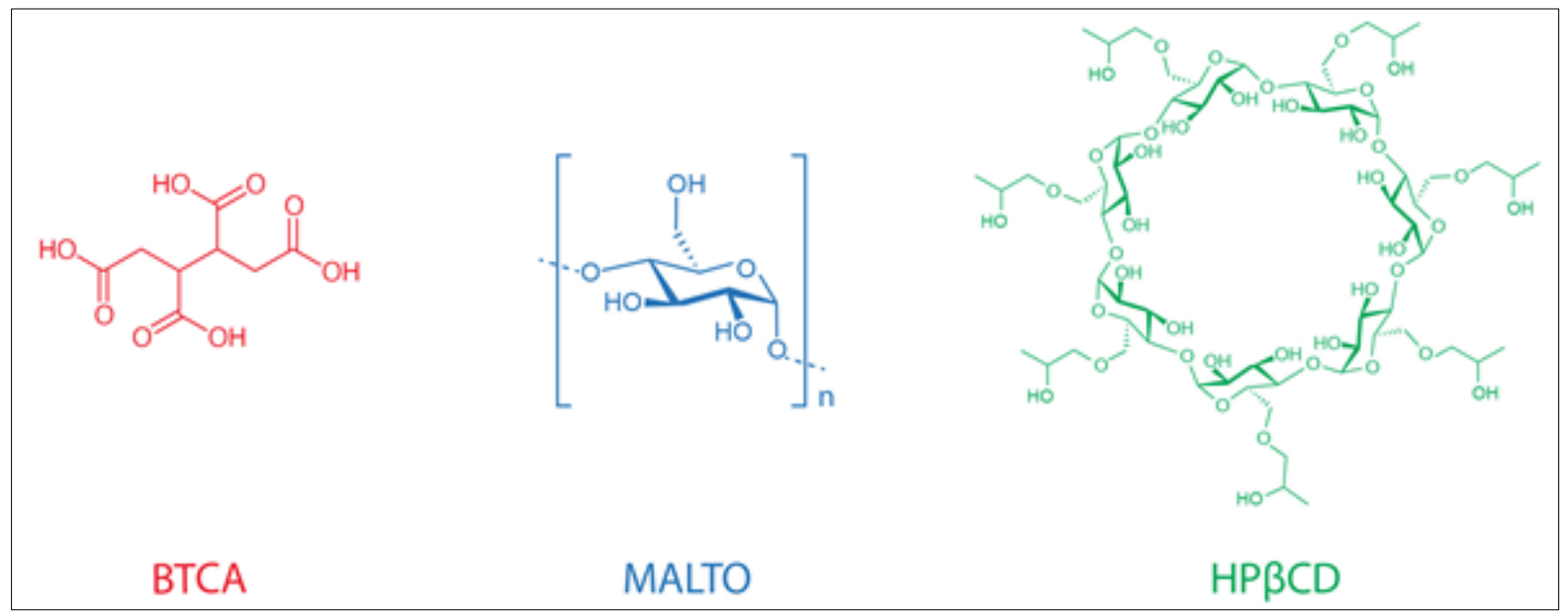

Scheme 1. Chemical structure of 1,2,3,4-butanetetracarboxylic acid (BTCA), maltodextrin (MALTO), and hydroxypropyl- $\beta$-cyclodextrin (HP $\beta C D)$

During the synthesis, a cross-linking reaction occurs by esterification in three possible cases (Scheme 2), depending on the reagents used: (1) a reaction between the BTCA carboxylic groups and the cellulose hydroxyl groups of hemp fibers (synthesis of HEMPBA); (2) an esterification between the BTCA carboxylic groups and the MALTO hydroxyl groups on the one hand, and cellulose hydroxyl groups of hemp fibers on the other hand (HEMPM); and (3) a cross-linking reaction between the BTCA carboxylic groups and the HP $\beta C D$ hydroxyl groups on the one hand, and cellulose hydroxyl groups of hemp fibers on the other hand (HEMPCD). BTCA undergoes a first dehydration under heating to give a 6-membered cyclic anhydride that reacts easily with a cellulose of MALTO (or HP $\beta C D$ ) anhydroglucose unit, forming a first ester group and returning a free carboxylic group [32-34]. Two remaining free carboxylic groups of esterified BTCA then form a second cyclic anhydride, which also reacts by esterification with cellulose or MALTO (or HP $\beta C D$ ) anhydroglucose units, releasing another free carboxylic acid group. This leads to a cross-linked polysaccharide network rich in carboxylic groups (scheme 2). Table 1 reports the characteristics of the four hemp-based materials used in this work.

Table 1. General description and properties of materials

\begin{tabular}{|c|c|c|c|c|}
\hline Code & HEMP & HEMPBA & HEMPM & HEMPCD \\
\hline Raw material & fiber & fiber & fiber & fiber \\
\hline Form & felt & felt & felt & felt \\
\hline Cross-linking agent & & BTCA & BTCA & BTCA $^{1}$ \\
\hline Matrix & & & MALTO & HP $^{1}$ \\
\hline Functional group & & carboxylate & carboxylate & carboxylate \\
\hline IEC & & $1.41 \pm 0.04$ & $1.08 \pm 0.03$ & $1.18 \pm 0.16$ \\
\hline Ionic form-shipped & $0.19 \pm 0.09$ & Na & Na & Na \\
\hline$\%$ C & & 45.9 & 53.2 & 55.5 \\
\hline$\% S$ & 42.7 & 0.28 & 0.31 & 0.32 \\
\hline
\end{tabular}

${ }_{1}^{1}, 2,3,4$-butanetetracarboxylic acid

${ }^{2}$ Maltodextrin

${ }^{3}$ Hydroxypropyl- $\beta$-cyclodextrin

${ }^{4}$ Ion exchange capacity, in meq/g 


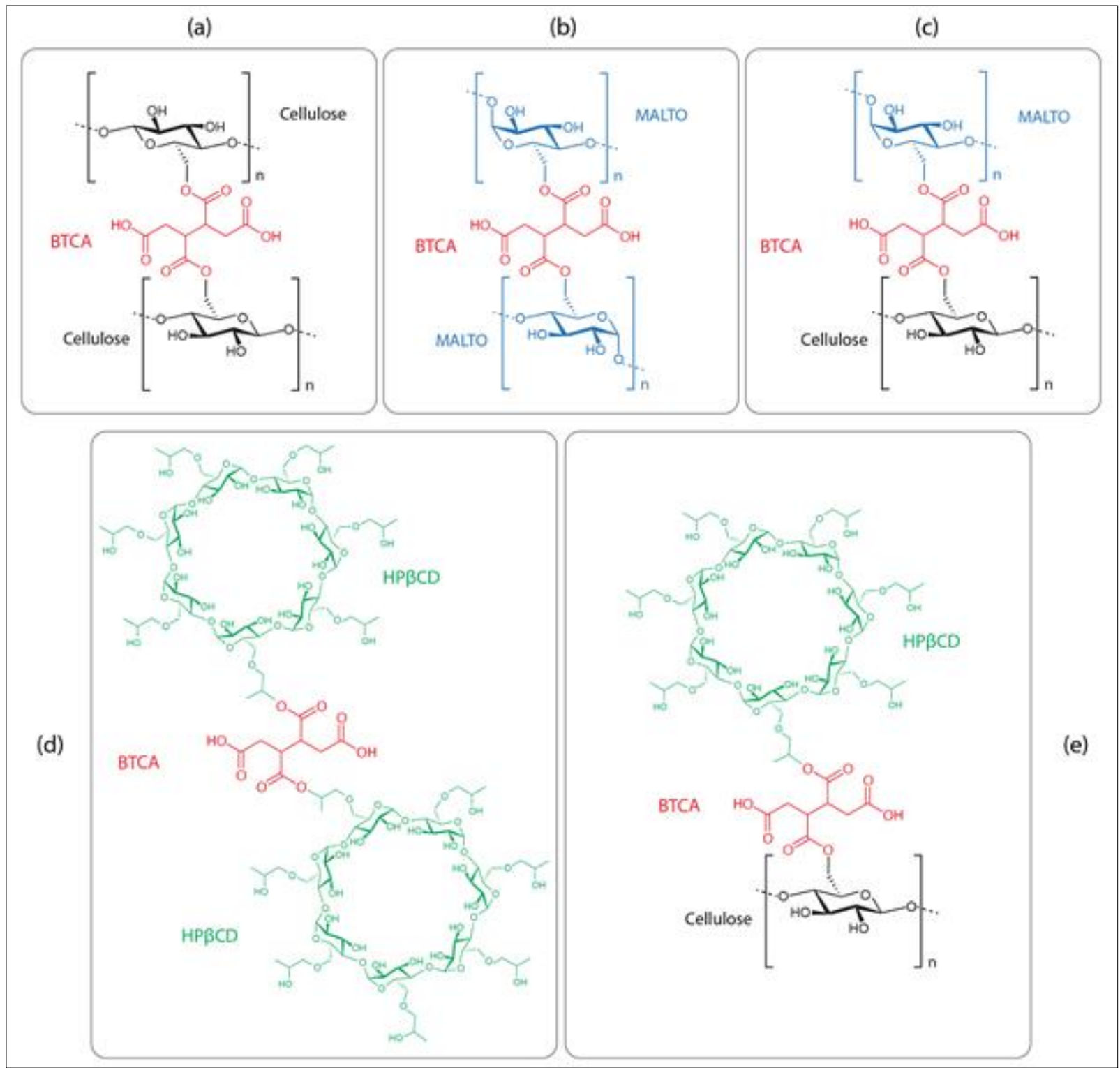

Scheme 2. Possible reactions between 1,2,3,4-butanetetracarboxylic acid (BTCA) and anhydro glucose units of: a) two cellulose chains; b) two maltodextrins (MALTO), c) one MALTO and one cellulose chain; d) two hydroxypropyl- $\beta$-cyclodextrin (HP $\beta C D)$; and e) one HP $\beta C D$ and one cellulose chain

\subsection{Industrial wastewaters}

Three wastewaters taken on three consecutive weeks, noted W1, W2 and W3, were collected from VMC Pêche Company located in Morvillars (Territoire de Belfort, France). This metal-finishing factory is specialized in fishing hook design and production. To treat these effluents, the company uses a physicochemical treatment involving two main stages to achieve the desired contaminant removal: (i) a pretreatment using chemical methods (e.g. specific treatment for reducing CrVI in CrIII) and (ii) neutralization steps using hydrated lime as a precipitant insolubilizing minerals such as metals and fluorides). Then, the treated effluent is flocculated and is finally decanted and filtered before being discharged into the aquatic environment if it complies with the regulatory standards. From a chemical point of view, the main industrial concerns are the COD values and the concentrations of nitrates, $\mathrm{Ni}$, $\mathrm{Cu}, \mathrm{Zn}$, total $\mathrm{Fe}+\mathrm{Al}$, cyanides, and chloroform. The wastewaters, i.e. raw effluents, from production lines studied in this work were collected before being sent to the treatment plant. 


\subsection{Analytical methods}

Full chemical characterization of the samples was carried out by measuring 13 standard water parameters and over 170 chemical substances. The choice of parameters and substances was determined by the regulatory requirements specifically laid down for the surface treatment industry as stipulated in the French Law of 5 September 2006. The water parameters monitored were: $p \mathrm{H}$, conductivity, suspended solids (SS), chemical oxygen demand (COD), total organic content (TOC), the levels of the different forms of nitrogen (nitrates, nitrites and ammonium nitrogen), cyanides (total and easily released), adsorbable halogenated organic compounds (AOX), free chlorine and hydrocarbon index (HI). To identify the inorganic and organic substances present in each wastewater, we analyzed eight broad family of substances classified as follows (in agreement with the French Water Authority): 46 inorganic substances including 33 metals, 58 volatile organic compounds (VOCs), 16 polycyclic aromatic compounds (PAHs), 24 chlorophenols (CPs), 16 alkylphenols (APs), 5 chloroaniline (CAs), 7 polychlorobiphenyls (PCBs) and 4 organo-tin complexes. All the protocols have already been detailed elsewhere $[28,31,35,36]$. The analytical characteristics of three samples, taken on three consecutive weeks, are shown in Table 2 (water parameters), Table 3 (inorganic contaminants), and Table 4 (organic contaminants).

Table 2. Standard water parameters for three wastewaters noted W1, W2 and W3 (SS: suspended solids, COD: chemical oxygen demand; TOC: total organic content; $\mathrm{CN}_{\mathrm{T}}$ : total cyanide; $\mathrm{AOX}$ : adsorbable halogenated organic compounds; HI: hydrocarbon index)

\begin{tabular}{|c|c|c|c|c|c|}
\hline Parameter & Unit & $\mathrm{QL}^{1}$ & Wl & W2 & W3 \\
\hline $\mathrm{pH}\left(20^{\circ} \mathrm{C}\right)$ & & & 4.7 & 5 & 4.3 \\
\hline conductivity $\left(20^{\circ} \mathrm{C}\right)$ & $\mu \mathrm{S} / \mathrm{cm}$ & & 8950 & 11500 & 7000 \\
\hline SS & $\mathrm{mg} / \mathrm{L}$ & 2 & 21 & 30 & 15 \\
\hline COD & $\mathrm{mg} / \mathrm{L}$ & 5 & 850 & 600 & 510 \\
\hline TOC & $\mathrm{mg} / \mathrm{L}$ & 0.5 & 95 & 88 & 71 \\
\hline nitrates & $\mathrm{mg} / \mathrm{L}$ & 1 & 200 & 230 & 185 \\
\hline nitrites & $\mathrm{mg} / \mathrm{L}$ & 1 & $<Q L$ & $<Q L$ & $\approx Q L$ \\
\hline ammonium nitrogen & $\mathrm{mg} / \mathrm{L}$ & 0.05 & 1.55 & 2.65 & 1.1 \\
\hline $\mathrm{CN}_{\mathrm{T}}$ & $\mathrm{mg} / \mathrm{L}$ & 0.02 & $<Q$ & $<\mathrm{QL}$ & $\therefore Q$ \\
\hline easily released cyanide & $\mathrm{mg} / \mathrm{L}$ & 0.02 & $<Q L$ & $<Q$ & $\therefore Q$ \\
\hline free chlorine & $\mu \mathrm{gcl} / \mathrm{L}$ & 0.02 & $\angle Q L$ & $<Q L$ & $\therefore Q$ \\
\hline AOX & $\mu \mathrm{g} / \mathrm{L}$ & 10 & 2000 & 3650 & 5000 \\
\hline HI & $\mathrm{mg} / \mathrm{L}$ & 0.1 & $<Q L$ & $<Q$ & $\approx Q L$ \\
\hline
\end{tabular}

${ }^{1}$ Quantification limit

Table 3. Concentrations of the inorganic substances (16 metals and 12 minerals) present in three wastewaters noted $\mathrm{W} 1, \mathrm{~W} 2$ and $\mathrm{W} 3$

\begin{tabular}{|c|c|c|c|c|c|}
\hline Parameter & Unit & $\mathbf{Q L}^{\mathbf{1}}$ & $\mathbf{W 1}$ & W2 & W3 \\
\hline aluminum & $\mathrm{mg} / \mathrm{L}$ & 0.02 & 0.94 & 2.21 & 4.9 \\
cadmium & $\mathrm{mg} / \mathrm{L}$ & 0.002 & 0.11 & 0.088 & 0.15 \\
cobalt & $\mathrm{mg} / \mathrm{L}$ & 0.003 & 9.2 & 2.21 & 6.5 \\
chromium & $\mathrm{mg} / \mathrm{L}$ & 0.005 & 1.33 & 0.25 & 0.61 \\
copper & $\mathrm{mg} / \mathrm{L}$ & 0.005 & 10.35 & 6.69 & 8.89 \\
iron & $\mathrm{mg} / \mathrm{L}$ & 0.02 & 350 & 200 & 460 \\
manganese & $\mathrm{mg} / \mathrm{L}$ & 0.005 & 25.3 & 38.2 & 18.9 \\
molybdenum & $\mathrm{mg} / \mathrm{L}$ & 0.01 & 0.36 & 0.29 & 0.15 \\
nickel & $\mathrm{mg} / \mathrm{L}$ & 0.01 & 3.77 & 5.32 & 4.89 \\
\hline
\end{tabular}




\begin{tabular}{|c|c|c|c|c|c|}
\hline lead & $\mathrm{mg} / \mathrm{L}$ & 0.002 & $<Q L$ & 0.061 & 0.075 \\
\hline zinc & $\mathrm{mg} / \mathrm{L}$ & 0.01 & 10.5 & 17.3 & 31.6 \\
\hline lithium & $\mathrm{mg} / \mathrm{L}$ & 0.02 & $<\mathrm{QL}$ & 0.09 & 0.073 \\
\hline tin & $\mathrm{mg} / \mathrm{L}$ & 0.005 & 0.051 & 0.078 & 0.022 \\
\hline strontium & $\mathrm{mg} / \mathrm{L}$ & 0.02 & 0.666 & 0.34 & 0.51 \\
\hline titane & $\mathrm{mg} / \mathrm{L}$ & 0.01 & $<\mathrm{QL}$ & 0.15 & 0.209 \\
\hline vanadium & $\mathrm{mg} / \mathrm{L}$ & 0.01 & 0.035 & 0.059 & 0.019 \\
\hline magnesium & $\mathrm{mg} / \mathrm{L}$ & 1 & 150 & 95 & 75 \\
\hline phosphorus & $\mathrm{mg} / \mathrm{L}$ & 0.16 & 1.15 & 1.25 & 1.1 \\
\hline boron & $\mathrm{mg} / \mathrm{L}$ & 0.02 & 50 & 41 & 36.8 \\
\hline sodium & $\mathrm{mg} / \mathrm{L}$ & 1 & 380 & 335 & 440 \\
\hline calcium & $\mathrm{mg} / \mathrm{L}$ & 5 & 300 & 270 & 385 \\
\hline potassium & $\mathrm{mg} / \mathrm{L}$ & 0.5 & 43.5 & 31.9 & 25.4 \\
\hline sulfide & $\mathrm{mg} / \mathrm{L}$ & 2 & 29.9 & 33.5 & 18.5 \\
\hline silicon & $\mathrm{mg} / \mathrm{L}$ & 0.01 & 20 & 15 & 17.5 \\
\hline fluorides & $\mathrm{mg} / \mathrm{L}$ & 0.5 & 23.5 & 16.7 & 18.2 \\
\hline chlorides & $\mathrm{mg} / \mathrm{L}$ & 1 & 900 & 1150 & 1080 \\
\hline bromide & $\mathrm{mg} / \mathrm{L}$ & 1 & 38 & 80 & 55 \\
\hline sulphates & $\mathrm{mg} / \mathrm{L}$ & 2 & 3100 & 4250 & 2890 \\
\hline
\end{tabular}

Table 4. Concentrations of organic substances (9 VOCs, 10 APs, 7 CPs and 5 PAHs) in three wastewaters noted $\mathrm{W} 1, \mathrm{~W} 2$ and $\mathrm{W} 3$

\begin{tabular}{|c|c|c|c|c|c|}
\hline Parameter & Unit & $\mathbf{Q L}^{1}$ & W1 & W2 & W3 \\
\hline chloroform & $\mu \mathrm{g} / \mathrm{L}$ & 0.5 & 150 & 350 & 200 \\
\hline 1,2-dichloroethane & $\mu \mathrm{g} / \mathrm{L}$ & 0.5 & $<\mathrm{QL}$ & 6.65 & 2.5 \\
\hline dichloromethane & $\mu \mathrm{g} / \mathrm{L}$ & 0.5 & 7.55 & 5.3 & 6.05 \\
\hline tetrachloroethylene & $\mu \mathrm{g} / \mathrm{L}$ & 0.5 & $<\mathrm{QL}$ & 26 & $<\mathrm{QL}$ \\
\hline trichloroethylene & $\mu \mathrm{g} / \mathrm{L}$ & 0.5 & 1.45 & 1.26 & $<\mathrm{QL}$ \\
\hline nonylphenol & $\mu \mathrm{g} / \mathrm{L}$ & 0.5 & 75 & 350 & 240 \\
\hline 4-tert-octylphenol & $\mu \mathrm{g} / \mathrm{L}$ & 0.5 & $<\mathrm{QL}$ & 4 & $<Q L$ \\
\hline 4-tert-butylphenol & $\mu \mathrm{g} / \mathrm{L}$ & 0.5 & $<\mathrm{QL}$ & 5.1 & $<\mathrm{QL}$ \\
\hline nonylphenol monoethoxylate & $\mu \mathrm{g} / \mathrm{L}$ & 0.1 & 0.12 & 0.44 & 0.3 \\
\hline nonylphenol diethoxylate & $\mu \mathrm{g} / \mathrm{L}$ & 0.1 & 1.05 & $<\mathrm{QL}$ & 0.91 \\
\hline nonylphenol monoethoxylate & $\mu \mathrm{g} / \mathrm{L}$ & 0.1 & 1.5 & 0.44 & 3.66 \\
\hline nonylphenol diethoxylate & $\mu \mathrm{g} / \mathrm{L}$ & 0.1 & $<\mathrm{QL}$ & 10 & $<\mathrm{QL}$ \\
\hline 2-methylphenol & $\mu \mathrm{g} / \mathrm{L}$ & 0.05 & 0.071 & $<\mathrm{QL}$ & 0.06 \\
\hline 3-methylphenol & $\mu \mathrm{g} / \mathrm{L}$ & 0.05 & 0.05 & 0.19 & 0.11 \\
\hline 4-methylphenol & $\mu \mathrm{g} / \mathrm{L}$ & 0.05 & $<\mathrm{QL}$ & 0.07 & $<\mathrm{QL}$ \\
\hline 2-chlorophenol & $\mu \mathrm{g} / \mathrm{L}$ & 0.05 & $<\mathrm{QL}$ & 0.15 & 0.5 \\
\hline 4-chlorophenol & $\mu \mathrm{g} / \mathrm{L}$ & 0.05 & $<\mathrm{QL}$ & $<\mathrm{QL}$ & 1 \\
\hline 2,4-dichlorophenol & $\mu \mathrm{g} / \mathrm{L}$ & 0.05 & $<\mathrm{QL}$ & 0.9 & 1.2 \\
\hline 2,3-dichlorophenol & $\mu \mathrm{g} / \mathrm{L}$ & 0.05 & 0.08 & $<\mathrm{QL}$ & $<\mathrm{QL}$ \\
\hline 3,4-chlorophenol & $\mu \mathrm{g} / \mathrm{L}$ & 0.05 & $<\mathrm{QL}$ & 0.15 & $<\mathrm{QL}$ \\
\hline 2,4,6-trichlorophenol & $\mu \mathrm{g} / \mathrm{L}$ & 0.25 & 3.65 & 2.1 & 2.5 \\
\hline 1,2-dichlorobenzene & $\mu \mathrm{g} / \mathrm{L}$ & 0.5 & 51.6 & 109 & 84.2 \\
\hline 4-chloro-3-methylphenol & $\mu \mathrm{g} / \mathrm{L}$ & 0.05 & $<\mathrm{QL}$ & 0.33 & 0.25 \\
\hline toluene & $\mu \mathrm{g} / \mathrm{L}$ & 1 & 18 & 25 & $<Q L$ \\
\hline anthracene & $\mu \mathrm{g} / \mathrm{L}$ & 0.01 & 0.15 & $<\mathrm{QL}$ & 0.2 \\
\hline
\end{tabular}




\begin{tabular}{|c|c|c|c|c|c|}
\hline phenanthrene & $\mu \mathrm{g} / \mathrm{L}$ & 0.01 & 0.2 & 0.17 & 0.19 \\
\hline naphthalene & $\mu \mathrm{g} / \mathrm{L}$ & 0.01 & 1.1 & 0.51 & 1.55 \\
\hline fluoranthene & $\mu \mathrm{g} / \mathrm{L}$ & 0.01 & $<\mathrm{QL}$ & 0.15 & 0.24 \\
\hline pyrene & $\mu \mathrm{g} / \mathrm{L}$ & 0.01 & 0.018 & $<\mathrm{QL}$ & 0.01 \\
\hline ethylbenzene & $\mu \mathrm{g} / \mathrm{L}$ & 0.01 & 1.45 & $<\mathrm{QL}$ & $<\mathrm{QL}$ \\
\hline isopropylbenzene & $\mu \mathrm{g} / \mathrm{L}$ & 0.5 & 1.1 & 1 & $<\mathrm{QL}$ \\
\hline
\end{tabular}

${ }^{1}$ Quantification limit

\subsection{Ecotoxicological methods}

To determine the potential toxicity of the wastewaters before and after hemp treatment, two ecotoxicological tests were also carried out [35-38]. The first is a standardized bioassay based of the mobility of Daphnia magna according to the "Inhibition Protocol Mobility" described in the standardized biomonitoring test ISO 6341-2012. The toxicity was expressed by the EC50, i.e. effective concentration corresponding to 50\% inhibition compared to controls, given in percentage of wastewaters. In France, the French Water Authority, a public organization involved in actions to counter pollution, imposes on certain companies the use of this bioassay to check the ecotoxicity of their treated waters before discharge into the aquatic environment. The second test is based on measurements of the germination rate of Lactuca sativa seeds (AFNOR NF X 31-201). The results are expressed in percentage germination, with respect to seeds not exposed to the wastewater (control). Our group previously demonstrated that these phytotoxicity tests were simple, quick and reliable, with the advantage of being inexpensive, and useful to assess the impact of industrial effluents before their discharge $[37,38]$. The two protocols used to evaluate the potential toxicity of the wastewaters before and after hemp treatment have already been detailed elsewhere $[35,36]$. The ecotoxicological characteristics of three samples are shown in Table 5.

Table 5. Toxicity values expressed in EC50 (effective concentration corresponding to 50\% inhibition compared to controls) in percentage of wastewater for Daphnia magna and in \% of germination of Lactuca sativa (germination rate value for the controls: $95 \% \pm 0.5 \%$ ) for three wastewaters before hemp treatment $(\mathrm{n}=3, \pm 0.5 \%)$

\begin{tabular}{|c|c|c|c|c|}
\hline Bio-indicator & & W1 & W2 & W3 \\
\hline${\text { Daphnia } \text { magna }^{1}}^{\mathbf{1}}$ & EC50 $^{2}$ & 0.7 & 3.1 & 2.7 \\
\hline Lactuca sativa $^{\mathbf{3}}$ & germination in $\%$ & 20.1 & 10.5 & 15.9 \\
\hline
\end{tabular}

${ }^{1} \mathrm{n}=1,{ }^{2} \mathrm{EC} 50=$ effective concentration, expressed in percentage of wastewater, ${ }^{3} \mathrm{n}=3$

\subsection{Batch experiments}

Contaminant removal from wastewater by adsorption on hemp-based materials (HEMP, HEMPBA, HEMPM and HEMPCD) was studied by a batch method without changing the initial $p \mathrm{H}$ of the raw effluent. In each experiment, $30 \mathrm{~g}$ of hemp felt were stirred with $15 \mathrm{~L}$ of wastewater for $30 \mathrm{~min}$ at a constant stirring rate $(250 \mathrm{rpm})$ and room temperature $\left(20 \pm 1^{\circ} \mathrm{C}\right)$. These conditions have been determined in preliminary studies [28-31]. After treatment, the felt was then withdrawn and the treated wastewater analyzed. The three samples were treated under identical conditions. When the value of a water parameter or of a substance concentration was lower than the quantification limit (QL), the values of this limit were taken into account to calculate the average values, in agreement with the French Water Authority standards [35]. 


\section{Results and discussions}

\subsection{Analytical characterization of the wastewaters}

The primary aim of this study was to identify and quantify the substances present in industrial wastewaters by measuring 13 standard water parameters and over 170 chemical substances. The analytical characterization of three samples, taken on three consecutive weeks, is presented in Table 2 (water parameters), Table 3 (inorganic contaminants) and Table 4 (organic contaminants). The total number of substances identified and quantified before hemp treatment in samples is shown in Table 6 (identification) and Table 7 (quantification). A general analysis of all these results showed that industrial effluents contained both mineral and organic contamination and they are not constant in either quality or quantity. The number of contaminants (metals + other minerals + organics) were 45, 53 and 49 for W1, W2 and W3, respectively (Table 6). Of the 170 substances monitored, 40 were always found in wastewaters: 30 inorganics (16 metals and 14 other minerals) and 10 organics (3 VOCs, 4 APs, 1 CP and 2 PAHs). The quantities of contaminants in samples is important (Table 7). For instance, the values for W1 are $413 \mathrm{mg}$ of metals, $5238 \mathrm{mg}$ of other minerals, $232 \mu \mathrm{g}$ of COVs, $79 \mu \mathrm{g}$ of APs, $3.98 \mu \mathrm{g}$ of CPs and $1.48 \mu \mathrm{g}$ of PAHs for $1 \mathrm{~L}$. The chemical composition in wastewaters can be ranked as follows: $\mathrm{W} 2>\mathrm{W} 3>\mathrm{W} 1$ for the number of substances, W3 $>\mathrm{W} 1>\mathrm{W} 2$ for the quantities of metals, CPs and PAHs, W2 $>$ W1 $>$ W3 for the quantities of other minerals, and W2 $>$ W3 $>$ W1 for the quantities of COVs and APs.

Table 2 shows the analytical results obtained for water parameters measured, confirming the presence of a mineral and organic polycontamination in samples with a high degree of qualitative and quantitative variability. The wastewaters were slightly acidic (mean $p \mathrm{H}$ of $4.6 \pm 0.3$ at $20^{\circ} \mathrm{C}$ ). They did not present significant turbidity (low levels of SS). On the other hand, they showed high conductivity (mean value of $9150 \pm 2257 \mu \mathrm{S} / \mathrm{cm}$ at $20^{\circ} \mathrm{C}$ ) and relatively high levels of organic pollution with a mean COD of 653 $\pm 176 \mathrm{mg} / \mathrm{L}$ and TOC of $84.7 \pm 12.3 \mathrm{mg} / \mathrm{L}$. High levels can also be seen in nitrates $(205 \pm 23 \mathrm{mg} / \mathrm{L})$ and AOX $(3550 \pm 1502 \mu \mathrm{gCl} / \mathrm{L})$. The cyanides (total and easily released), nitrites, free chlorine and hydrocarbon index were lower than the quantification limit (Table 2).

The results reported in Table 3 confirm the high salinity of wastewaters with high levels of sulphates (mean value of $3413 \pm 732 \mathrm{mg} / \mathrm{L}$ ), chlorides $(1043 \pm 129 \mathrm{mg} / \mathrm{L}$ ), sodium $(385 \pm 53 \mathrm{mg} / \mathrm{L}$ ), and calcium $(318 \pm 60 \mathrm{mg} / \mathrm{L}$ ). Sixteen metals were found at quantifiable levels (Al, Cd, Co, Cr, Cu, Fe, Mn, Mo, Ni, $\mathrm{Pb}, \mathrm{Zn}, \mathrm{Li}, \mathrm{Sn}, \mathrm{Sr}$, Ti and V). The concentration of other metals (Ag, As, Ba, CrVI, Sb, Hg, Pd, Pt, Te, $\mathrm{Tl}, \mathrm{W}$ ) remained below the limit of quantification. High levels can be seen in $\mathrm{Fe}$ (mean value of $337 \pm$ $131 \mathrm{mg} / \mathrm{L}), \mathrm{Mn}(27.5 \pm 9.8 \mathrm{mg} / \mathrm{L}), \mathrm{Zn}(19.8 \pm 10.8 \mathrm{mg} / \mathrm{L}), \mathrm{Cu}(8.64 \pm 1.84 \mathrm{mg} / \mathrm{L}), \mathrm{Co}(5.97 \pm 3.53 \mathrm{mg} / \mathrm{L})$, $\mathrm{Ni}(4.66 \pm 0.80 \mathrm{mg} / \mathrm{L})$, and $\mathrm{Al}(2.68 \pm 2.02 \mathrm{mg} / \mathrm{L})$. Fourteen other minerals (phosphorus, boron, magnesium, sodium, calcium, potassium, sulfur, silicon, fluorides, chlorides, bromide, sulphates, ammonium and nitrates) were systematically found in samples. Thirty-one organic substances were identified and quantified including 9 VOCs, 10 APs, 7 CPs and 5 PAHs (Table 4). However, only ten substances (chloroform, dichloromethane, nonylphenol, nonylphenol monoethoxylate, octylphenol monoethoxylate, 3-methylphenol, 2,4,6-trichlorophenol, 1,2-dichlorobenzene, phenanthrene and naphthalene) were systematically found in the three samples. High levels can be seen in chloroform (mean value of $233 \pm 10 \mu \mathrm{g} / \mathrm{L}$ ), nonylphenol $(221.6 \pm 138 \mu \mathrm{g} / \mathrm{L}), 1,2$-dichlorobenzene $(81.6 \pm 28.8$ $\mu \mathrm{g} / \mathrm{L})$, and tetrachloroethylene $(9 \pm 14.7 \mu \mathrm{g} / \mathrm{L})$. Wastewaters did not contain any choroanilines, polychlorobiphenyls and organo-tin (values lower than the quantification limit). 
Table 6. Recap of the total number of substances identified before and after hemp treatment in wastewaters noted W1, W2 and W3 (VOCs: volatile organic compounds; APs: alkylphenols;

CPs: chlorophenols; PAHs: polycyclic aromatic compounds)

\begin{tabular}{|c|c|c|c|c|c|c|c|}
\hline Wastewater & Metals & VOCs & APs & CPs & PAHs & $\begin{array}{l}\text { Other inorganic } \\
\text { contaminants }^{1}\end{array}$ & Total \\
\hline W 1 & 13 & 7 & 6 & 3 & 3 & 13 & 45 \\
\hline Wl treated by HEMP & 11 & 6 & 4 & 2 & 0 & 13 & 36 \\
\hline W1 treated by HEMPBA & 4 & 6 & 6 & 3 & 0 & 11 & 32 \\
\hline W1 treated by HEMPM & 9 & 4 & 4 & 2 & 0 & 13 & 32 \\
\hline W1 treated by HEMPCD & 8 & 0 & 1 & 2 & 0 & 13 & 24 \\
\hline & & & & & & & \\
\hline W 2 & 16 & 7 & 8 & 6 & 3 & 13 & 53 \\
\hline W2 treated by HEMP & 13 & 6 & 7 & 5 & 3 & 13 & 47 \\
\hline W2 treated by HEMPBA & 5 & 7 & 8 & 6 & 3 & 13 & 42 \\
\hline W2 treated by HEMPM & 12 & 6 & 7 & 6 & 2 & 13 & 46 \\
\hline W2 treated by HEMPCD & 8 & 3 & 2 & 1 & 0 & 13 & 27 \\
\hline W 3 & 16 & 4 & 6 & 6 & 4 & 13 & 49 \\
\hline W3 treated by HEMP & 11 & 3 & 3 & 5 & 4 & 13 & 40 \\
\hline W3 treated by HEMPBA & 6 & 4 & 5 & 5 & 3 & 13 & 36 \\
\hline W3 treated by HEMPM & 12 & 3 & 3 & 5 & 2 & 13 & 38 \\
\hline W3 treated by HEMPCD & 9 & 1 & 1 & 2 & 0 & 13 & 26 \\
\hline
\end{tabular}

'phosphorus, boron, magnesium, sodium, calcium, potassium, sulfide, silicon, fluorides, chlorides, bromide,

sulphates, ammonium, nitrates

Table 7. Recap of the quantities of contaminants before and after hemp treatment in wastewaters noted W1, W2 and W3 (metals and other contaminants in mg/L;

VOCs, APs, CPs and PAHs in $\mu \mathrm{g} / \mathrm{L}$ )

\begin{tabular}{|c|c|c|c|c|c|c|c|}
\hline Wastewater & Metals & VOCs & APs & CPs & PAHs & $\begin{array}{l}\text { Other inorganic } \\
\text { contaminants }{ }^{1}\end{array}$ & Total \\
\hline W 1 & 13 & 7 & 6 & 3 & 3 & 13 & 45 \\
\hline Wl treated by HEMP & 11 & 6 & 4 & 2 & 0 & 13 & 36 \\
\hline W1 treated by HEMPBA & 4 & 6 & 6 & 3 & 0 & 11 & 32 \\
\hline Wl treated by HEMPM & 9 & 4 & 4 & 2 & 0 & 13 & 32 \\
\hline W1 treated by HEMPCD & 8 & 0 & 1 & 2 & 0 & 13 & 24 \\
\hline & & & & & & & \\
\hline W 2 & 16 & 7 & 8 & 6 & 3 & 13 & 53 \\
\hline W2 treated by HEMP & 13 & 6 & 7 & 5 & 3 & 13 & 47 \\
\hline W2 treated by HEMPBA & 5 & 7 & 8 & 6 & 3 & 13 & 42 \\
\hline W2 treated by HEMPM & 12 & 6 & 7 & 6 & 2 & 13 & 46 \\
\hline W2 treated by HEMPCD & 8 & 3 & 2 & 1 & 0 & 13 & 27 \\
\hline W 3 & 16 & 4 & 6 & 6 & 4 & 13 & 49 \\
\hline W3 treated by HEMP & 11 & 3 & 3 & 5 & 4 & 13 & 40 \\
\hline W3 treated by HEMPBA & 6 & 4 & 5 & 5 & 3 & 13 & 36 \\
\hline W3 treated by HEMPM & 12 & 3 & 3 & 5 & 2 & 13 & 38 \\
\hline W3 treated by HEMPCD & 9 & 1 & 1 & 2 & 0 & 13 & 26 \\
\hline
\end{tabular}

${ }^{1}$ phosphorus, boron, magnesium, sodium, calcium, potassium, sulfide, silicon, fluorides, chlorides, bromide,

sulphates, ammonium, nitrates 


\subsection{Biological characterization of the wastewaters}

Environmental legislation in Europe highlights the complementarity of combined chemical and biological monitoring approaches [1]. In France, the French Water Authority requires certain companies to carry out a biological test to assess the ecotoxicity of their treated wastewaters before discharging it into the environment, and this trend is becoming widespread. However, while contaminant mixtures present in water in general are relatively easy to characterize chemically, assessing their impact on the environment is usually difficult and has rarely been reported. In addition, the toxicity of surface treatment waste remains poorly defined [31]. In this work, the toxicity of the three wastewaters before hemp treatment was studied using two bio-indicators, Daphnia magna and Lactuca sativa.

The EC50 values for D. magna and germination rates for $L$. sativa given in Table 5 indicate high toxicity. According to a French guide on the use of bioassays for the quality assessment of samples, the effluents were classified toxic if EC50 < 50\% and very toxic if EC50 < 10\%. The EC50 are very low for Daphnis indicating deleterious effects on this bio-indicator. The results also confirm that contaminants present in wastewater inhibited the germination of planted seeds (Table 5). An important decrease of the germination rate is observed (average germination rate value of $15.5 \% \pm 4.8 ; 95 \% \pm 0.5 \%$ for the controls). Metals, other minerals, organics, and other unidentified substances such as commercial organic preparations used by industrial (data are not available) could be responsible for the observed toxicity for the two bio-indicators.

To resume the analytical and ecotoxicological data, our survey demonstrated the contaminant load in the three wastewaters studied, taken on three consecutive weeks, varied over time both quantitatively and qualitatively, indicating the great variability of the pollution present in the different samples. From a chemical point of view, the chemical composition in wastewaters can be ranked as follows: W2 $>$ W3 $>\mathrm{W} 1$ for the number of substances, $\mathrm{W} 3>\mathrm{W} 1>\mathrm{W} 2$ for the quantities of metals, $\mathrm{W} 1>\mathrm{W} 2>\mathrm{W} 3$ for the total of organic load expressed as the sum of TOC and COD, and W2 $>$ W3 $>$ W1 for the total of organic substances expressed as the sum of quantities. For the two bioassays, the sample toxicity range (decreasing order) was $\mathrm{W} 1>\mathrm{W} 3>\mathrm{W} 2$ for $\mathrm{D}$. magna and $\mathrm{W} 2>\mathrm{W} 3>\mathrm{W} 1$ for L. sativa.

\subsection{Effect of hemp treatment on water parameters}

In Table 8, the values of water parameters of samples and the same samples treated with hemp are shown. By comparing all the results obtained, HEMPCD is more efficient than HEMP, HEMPBA and HEMPM in removing contamination. HEMPCD decreases COD, TOC (Figure 1) and AOX but has little effect on nitrates (Table 8). The average values for COD are $653 \mathrm{mg} / \mathrm{L} \pm 176$ for wastewaters, $575 \mathrm{mg} / \mathrm{L}$ \pm 201 for HEMP (corresponding to an abatement of 12\%), $595 \mathrm{mg} / \mathrm{L} \pm 198$ for HEMPBA (9\% abatement), $359 \mathrm{mg} / \mathrm{L} \pm 174$ for HEMPM (45\% abatement) and $113 \mathrm{mg} / \mathrm{L} \pm 29$ for HEMPCD (83\% abatement). These results clearly indicate the important role of cyclodextrin molecules to decrease organic load. This is also confirmed by the abatement values for TOC: 12\%, 7\%, 26 and 53\% for HEMP, HEMPBA, HEMPM and HEMPCD, respectively. The average AOX value also decreases significantly after HEMPCD treatment (78\% abatement). The three modified hemp materials, in the order HEMPM $\sim$ HEMPCD < HEMPBA, decreased ammonium concentration, suggesting strong chemical interactions between carboxylate groups and ammonium groups, in agreement with literature data [39-41]. 
Table 8. Average values (standard deviation) for water parameters of three wastewaters before and after hemp treatment $\left(p \mathrm{H}\right.$ at $20^{\circ} \mathrm{C}$; conductivity in $\mu \mathrm{S} / \mathrm{cm}$ at $20^{\circ} \mathrm{C}$; concentrations expressed in $\mathrm{mg} / \mathrm{L}$; SS suspended solids; COD chemical oxygen demand; TOC total organic carbon; AOX adsorbable halogenated organic compounds)

\begin{tabular}{|c|c|c|c|c|c|}
\hline Parameter & $\begin{array}{c}\text { Wastewater } \\
\text { before } \\
\text { treatment }\end{array}$ & $\begin{array}{c}\text { Wastewater } \\
\text { treated by } \\
\text { HEMP }\end{array}$ & $\begin{array}{c}\text { Wastewater } \\
\text { treated by } \\
\text { HEMPBA }\end{array}$ & $\begin{array}{c}\text { Wastewater } \\
\text { treated by } \\
\text { HEMPM }\end{array}$ & $\begin{array}{c}\text { Wastewater } \\
\text { treated by } \\
\text { HEMPCD }\end{array}$ \\
\hline pH & $4.7(0.4)$ & $4.8(0.3)$ & $4.9(0.3)$ & $5.1(0.4)$ & $5.3(0.2)$ \\
\hline conductivity & $9150(2257)$ & $5750(1689)$ & $5083(1355)$ & $5150(1676)$ & $5333(1527)$ \\
\hline SS & $22(8)$ & $16(5)$ & $17(6)$ & $15(5)$ & $15(5)$ \\
\hline COD & $653(176)$ & $575(201)$ & $595(198)$ & $359(174)$ & $113(29)$ \\
\hline TOC & $84.7(12.3)$ & $74.5(12.6)$ & $79(12.8)$ & $62.9(13.7)$ & $39.4(1.2)$ \\
\hline nitrates & $205(23)$ & $180(20)$ & $205(23)$ & $193(15)$ & $197(23)$ \\
\hline ammonium & $1.8(0.8)$ & $1.5(0.5)$ & $0.45(0.26)$ & $0.65(0.27)$ & $0.61(0.22)$ \\
\hline AOX & $3550(1502)$ & $2450(1076)$ & $2333(802)$ & $1633(592)$ & $763(131)$ \\
\hline
\end{tabular}

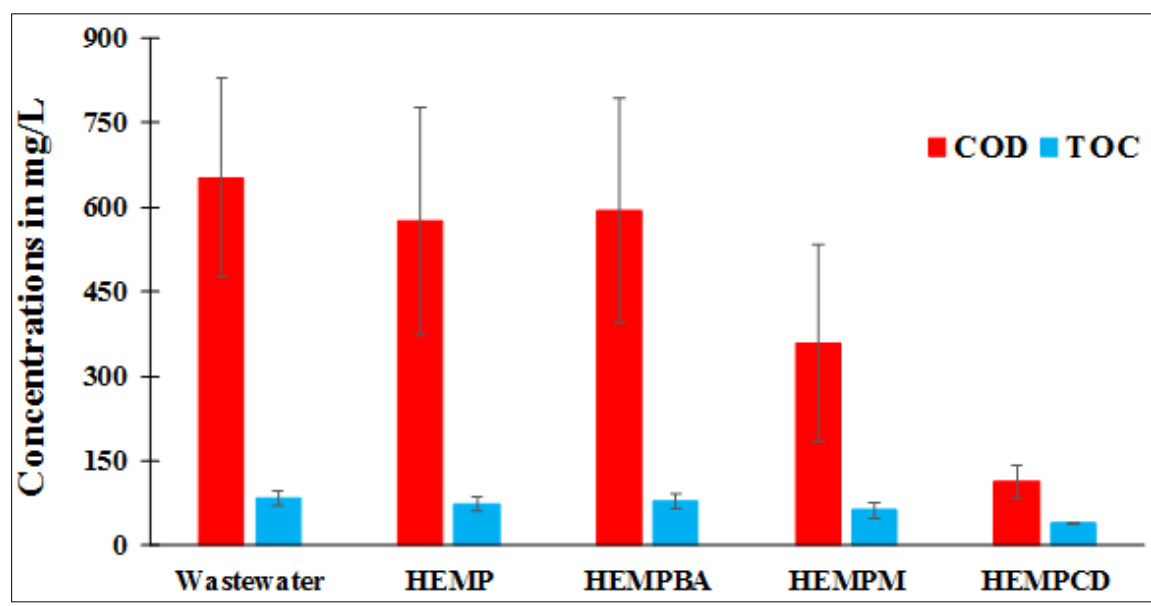

Figure 1. Concentrations (in $\mathrm{mg} / \mathrm{L}$ ) of chemical oxygen demand (COD) and total organic carbon (TOC) parameters for the three wastewaters before (raw wastewater) and after hemp treatment (HEMP, HEMPBA, HEMPM and HEMPCD)

\subsection{Effect of hemp treatment on inorganic contaminant removal}

The data presented in Table 9 show a significant elimination of metal contamination for each wastewater treated by hemp. However, the proposed treatment, using the conditions described in the material and method section, is not able to remove all substances present as reported in Table 7. Indeed, the main objective of this study was not to obtain optimal performance (which can be obtained by increasing the dose of material for example, as already published) [27,28] but to highlight the role of the material structure in its performance.

The four felts are efficient in reducing the metal load in effluents (Table 9, Figure 2), whatever the metal considered, but as expected, the abatements are very high for modified materials (Figure 2), pointing out the important role of carboxylate groups in chemisorption mechanism. These groups are responsible for metal cations binding through electrostatic interactions and ion-exchange [39-41], and their presence in HEMPBA, HEMPM and HEMPCD (respectively 1.41, 1.08 and 1.18 meq $\mathrm{COOH}$ groups per gram, against $0.19 \mathrm{meq} / \mathrm{g}$ for raw hemp) positively influenced their performance. Adsorption mechanism have already been discussed using data from scanning electron microscopy and energydispersive X-ray spectroscopy studies in our previous work [27,28]. HEMP is nevertheless effective in reducing the metallic load in samples, with metal-dependent performance. Good abatements have been obtained for $\mathrm{Co}, \mathrm{Fe}, \mathrm{Ni}, \mathrm{Mn}, \mathrm{Zn}$ and especially $\mathrm{Cu}$ (Table 9, Figure 2), in agreement with our previous works [26,29]. 
Comparing all the results obtained, the highest levels of metal removal are achieved with HEMPBA (Tables 7 and 9, Figure 2), whatever the wastewater treated, and this treatment effectively lowers the main metals, namely $\mathrm{Al}, \mathrm{Co}, \mathrm{Cu}, \mathrm{Fe}, \mathrm{Mn}, \mathrm{Ni}$ and $\mathrm{Zn}$, present in industrial wastewater (Table 9). For instance, for the three effluents, the average values for $\mathrm{Zn}$ are $19.8 \mathrm{mg} / \mathrm{L} \pm 10.8$ for wastewaters, 9.2 $\mathrm{mg} / \mathrm{L} \pm 6.9$ after treatment with HEMP (53\% abatement), $3.63 \mathrm{mg} / \mathrm{L} \pm 0.46$ for HEMPM $(81 \%$ abatement), $1.36 \mathrm{mg} / \mathrm{L} \pm 1.1$ for HEMPCD (93\% abatement), and $0.213 \mathrm{mg} / \mathrm{L} \pm 0.255$ for HEMPBA (98.7\% abatement). The average values of $\mathrm{Al}, \mathrm{Ni}$ and $\mathrm{Cu}$ concentrations also decrease significantly after HEMPBA treatment. The levels for $\mathrm{Cd}, \mathrm{Cr}, \mathrm{Cu}, \mathrm{Mo}, \mathrm{Ni}, \mathrm{Pb}, \mathrm{Li}, \mathrm{Ti}, \mathrm{Sn}, \mathrm{Sr}$ and $\mathrm{V}$ are below the limit of quantification (Table 9). Compared to HEMP, HEMPM and HEMPCD are more efficient in removing metals, reconfirming the role of carboxylate groups in the adsorption mechanism. However, the performance obtained for these two materials was lower than that obtained with material HEMPBA (Tables 7 and 9). So, the metal cations uptake by the materials can be correlated with their respective ion-exchange capacity (Table 1). In particular, as observed in Scheme 2, in the case of HEMPM and HEMPCD, two of the four carboxylic groups of BTCA are transformed into ester groups to provide a covalent bond with cellulose of hemp on the one hand, and with maltodextrin or cyclodextrin on the other hand, or a cross-linking between two maltodextrins or two cyclodextrins. Interestingly, in case of HEMPBA, probably cross-linking between two cellulose chains exposed on the surface of hemp occurs, but it can be supposed that BTCA can also be grafted on cellulose through only one ester linkage, resulting in three residual free carboxylic functions per BTCA instead of two. As a consequence, as confirmed by the titration assays, HEMPBA samples present more carboxylic groups with a better accessibility than those present on HEMPM and HEMPCD samples.

Notable differences are observed for Mn (Table 9, Figure 2). The average values for this metal are $25.7 \mathrm{mg} / \mathrm{L} \pm 9.8$ for wastewaters, $25 \mathrm{mg} / \mathrm{L} \pm 8.3$ for HEMP, $3.44 \mathrm{mg} / \mathrm{L} \pm 1.2$ for HEMPCD, $3.81 \mathrm{mg} / \mathrm{L}$ \pm 0.83 for HEMPM and $2.6 \mathrm{mg} / \mathrm{L} \pm 0.7$ for HEMPBA. These results clearly indicate a greater affinity for the carboxylate groups present in the modified felts (HEMPBA, HEMPM and HEMPCD) compared to raw felt (HEMP), confirming our previous results on Mn [27-29]. This higher removal corresponds to the preference of the carboxylate groups for this metal in accordance with HSAB theory for Pearson [43-45] and the classification proposed by Nieboer and Richardson [46]. In this theoretical concept, carboxylate groups are considered as hard base and then prefer hard acids such as Mn ions.

Modified materials were more efficient than HEMP to remove other inorganic contaminants. They decreased phosphorus, boron, calcium, potassium and sulfur concentrations (Tables 7 and 9), but had, as expected, no effect on fluorides, chlorides, bromide and sulphates, due to their anionic nature, which adversely affects interactions with carboxylate groups. Another observation must be noted (Table 9): an increase in the concentration of the sodium cations after hemp treatment, coupled with a decrease in the concentration of the metal ions, was systematically observed, indicating the replacement of the sodium cations by ion exchange. This has been demonstrated using energy-dispersive X-ray spectroscopy data, as recently published [27].

Table 9. Average values (standard deviation) for inorganic contaminants of three wastewaters before and after hemp treatment (concentrations expressed in $\mathrm{mg} / \mathrm{L}$ )

\begin{tabular}{|c|c|c|c|c|c|}
\hline Contaminant & $\begin{array}{c}\text { Wastewater before } \\
\text { treatment }\end{array}$ & $\begin{array}{c}\text { Wastewater } \\
\text { treated by } \\
\text { HEMP }\end{array}$ & $\begin{array}{c}\text { Wastewater } \\
\text { treated by } \\
\text { HEMPBA }\end{array}$ & $\begin{array}{c}\text { Wastewater } \\
\text { treated by } \\
\text { HEMPM }\end{array}$ & $\begin{array}{c}\text { Wastewater } \\
\text { treated by } \\
\text { HEMPCD }\end{array}$ \\
\hline aluminum & $2.68(2.02)$ & $1.8(1.4)$ & $0.307(0.205)$ & $0.82(0.44)$ & $0.55(0.3)$ \\
\hline cadmium & $0.116(0.031)$ & $<0.002$ & -0.002 & $0.028(0.045)$ & 00.002 \\
\hline cobalt & $5.97(3.53)$ & $3.2(1.8)$ & $0.607(0.251)$ & $1.4(0.67)$ & $1.15(0.566)$ \\
\hline chromium & $0.73(0.55)$ & $0.26(0.15)$ & -0.005 & $0.16(0.05)$ & $0.15(0.087)$ \\
\hline copper & $8.64(1.84)$ & $2.1(0.3)$ & -0.005 & $0.89(0.618)$ & $0.53(0.335)$ \\
\hline iron & $337(131)$ & $80.7(23.1)$ & $35.8(13.7)$ & $58.1(17.2)$ & $50.3(12.9)$ \\
\hline manganese & $25.7(9.8)$ & $25(8.3)$ & $2.6(0.7)$ & $3.81(0.83)$ & $3.44(1.2)$ \\
\hline
\end{tabular}




\begin{tabular}{|c|c|c|c|c|c|}
\hline molybdenum & $0.27(0.11)$ & $0.13(0.05)$ & $<0.01$ & $0.057(0.045)$ & $<0.01$ \\
\hline nickel & $4.66(0.8)$ & $1.12(0.22)$ & $<0.01$ & $0.057(0.045)$ & $<0.01$ \\
\hline lead & $0.046(0.039)$ & $<0.002$ & $<0.002$ & $<0.002$ & $<0.002$ \\
\hline zinc & $19.8(10.8)$ & $9.2(6.9)$ & $0.213(0.255)$ & $3.63(0.46)$ & $1.36(1.1)$ \\
\hline lithium & $0.061(0.037)$ & $0.03(0.017)$ & $<0.02$ & $<0.02$ & $<0.02$ \\
\hline tin & $0.05(0.028)$ & $0.017(0.015)$ & $<0.005$ & $0.007(0.003)$ & $<0.05$ \\
\hline strontium & $0.505(0.163)$ & $0.23(0.07)$ & $<0.02$ & $0.13(0.05)$ & $0.05(0.05)$ \\
\hline titane & $0.123(0.102)$ & $0.081(0.069)$ & $0.02(0.02)$ & $0.07(0.05)$ & $0.03(0.03)$ \\
\hline vanadium & $0.038(0.02)$ & $0.011(0.001)$ & $<0.01$ & $<0.01$ & $<0.01$ \\
\hline magnesium & $107(39)$ & $99.3(36.4)$ & $70.1(26.8)$ & $83.8(27.9)$ & $84.4(35.7)$ \\
\hline phosphorus & $1.167(0.076)$ & $0.84(0.056)$ & $0.647(0.119)$ & $0.523(0.046)$ & $0.386(0.021)$ \\
\hline boron & $42.6(6.7)$ & $35(5.6)$ & $20.4(10.5)$ & $29.4(5)$ & $28.7(12.1)$ \\
\hline sodium & $385(53)$ & $340(46)$ & $500(50)$ & $577(93)$ & $575(139)$ \\
\hline calcium & $318(60)$ & $298(55)$ & $247(55)$ & $257(93)$ & $242(52)$ \\
\hline potassium & $33.6(9.2)$ & $32.1(9.5)$ & $24.1(7.8)$ & $29.8(8.4)$ & $29.7(9.6)$ \\
\hline sulfur & $27.3(7.8)$ & $23.2(5.5)$ & $17.4(4)$ & $18.1(6.3)$ & $17.5(6.1)$ \\
\hline silicon & $17.5(2.5)$ & $16.4(2.1)$ & $11.8(1.3)$ & $13.9(1.9)$ & $14.1(1.2)$ \\
\hline fluorides & $19.5(3.6)$ & $13.5(4.4)$ & $19(2.7)$ & $17.5(2.8)$ & $17(3.8)$ \\
\hline chlorides & $1043(129)$ & $823(155)$ & $980(101)$ & $942(101)$ & $900(87)$ \\
\hline bromide & $57.7(21.1)$ & $40.9(19.4)$ & $57.7(21.1)$ & $54.7(21.6)$ & $52.3(18.6)$ \\
\hline sulphates & $3413(732)$ & $2767(833)$ & $3380(755)$ & $3183(711)$ & $3017(729)$ \\
\hline
\end{tabular}

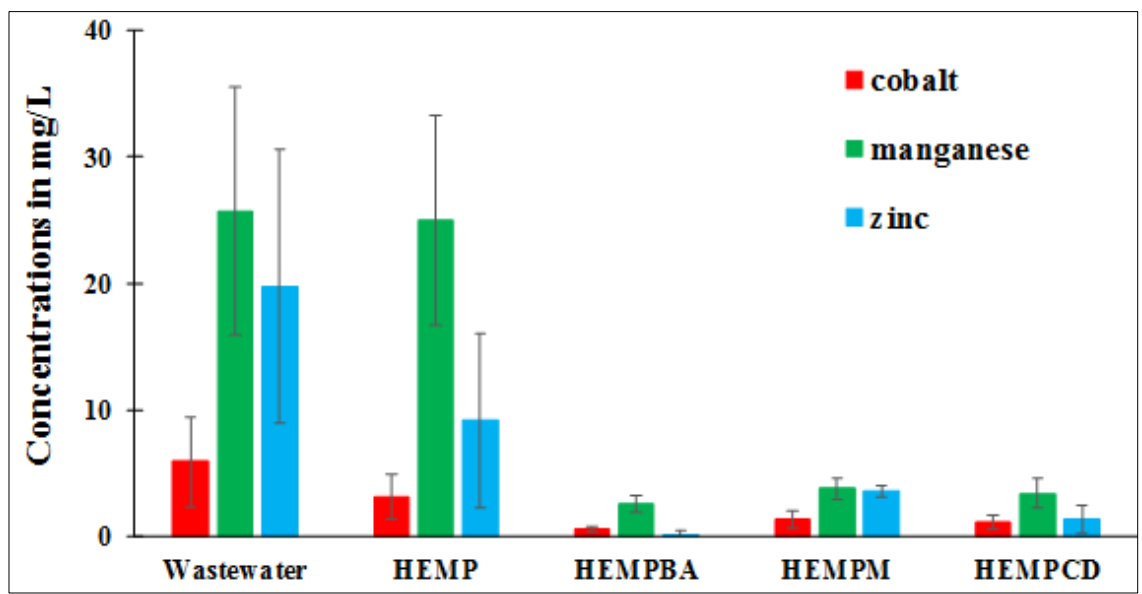

Figure 2. Concentrations (in $\mathrm{mg} / \mathrm{L}$ ) of cobalt, manganese and zinc for the three wastewaters before (raw wastewater) and after hemp treatment (HEMP, HEMPBA, HEMPM and HEMPCD)

\subsection{Effect of hemp treatment on organic contaminant removal}

The data presented in Table 10 and Figure 3 show a significant elimination of organic substances present in wastewaters treated by HEMPCD, with an important decrease of chloroform, nonylphenol, 1,2-dichlorobenzene and toluene. For instance, the average values for nonylphenol are $222 \mu \mathrm{g} / \mathrm{L} \pm 138$ for wastewaters, $163 \mu \mathrm{g} / \mathrm{L} \pm 109$ after HEMP treatment ( $26 \%$ abatement), $175 \mu \mathrm{g} / \mathrm{L} \pm 115$ for HEMPBA (14\% abatement), $60 \mu \mathrm{g} / \mathrm{L} \pm 28$ for HEMPM (72\% abatement) and $4.7 \mu \mathrm{g} / \mathrm{L} \pm 0.8$ for HEMPCD (97.8\% abatement). The levels of others contaminants are in the vicinity of or even below the limit of quantification after both HEMPCD and also HEMPM treatment. The total amount of organics (VOCs+APs+CPs+PAHs) decreases from $316 \mu \mathrm{g}$ for $\mathrm{W} 1$ to $185 \mu \mathrm{g}, 211 \mu \mathrm{g}, 91 \mu \mathrm{g}$ and $15.9 \mu \mathrm{g}$ for HEMP, HEMPBA, HEMPM and HEMCD treatments, respectively, showing that HEMPM and especially HEMPCD are able to remove the organic substances present in W1. Similar results were 
obtained for W2 and W3. The analysis of the results presented in Tables 7 and 10 also confirms that HEMP and especially HEMPBA are not very effective in reducing the organic load in wastewater even if some concentrations have decreased. For HEMPBA, it seems that its anionic and more hydrophilic nature disadvantages interactions with organics, whereas for HEMPM, the presence of the maltodextrin cross-linked polymer makes it possible to eliminate them. However, HEMPM was less effective than HEMPCD (Tables 7 and 10), whatever the wastewater treated, pointing out the important role of the cyclodextrin cavity in the adsorption mechanism. Indeed, considering both linear and cyclic dextrins, the chemical composition of the corresponding coatings on hemps is perfectly identical and the results obtained show that the organic pollutants specifically interact with the two cross-linked dextrins immobilized on the hemp fibers. However, the increased performances observed for HEMPCD compared to HEMPM clearly shows the benefit of the cavity of HP $\beta C D$ (Figure 3), which are responsible for the removing of contaminants by inclusion complexation [47]. It should be mentioned that among the abundant literature on cyclodextrin-based sorbents applied to wastewater decontamination and also to drug delivery systems, almost no studies report the use of a maltodextrinbased material as a control to highlight the involvement of host-guest phenomena in interactions between materials and pollutants or drugs.

Table 10. Average values (standard deviation) for organic contaminants of three wastewaters before and after hemp treatment (concentrations expressed in $\mu \mathrm{g} / \mathrm{L}$ )

\begin{tabular}{|c|c|c|c|c|c|}
\hline Contaminant & $\begin{array}{c}\text { Wastewater before } \\
\text { treatment }\end{array}$ & $\begin{array}{c}\text { Wastewater } \\
\text { treated by } \\
\text { HEMP }\end{array}$ & $\begin{array}{l}\text { Wastewater } \\
\text { treated by } \\
\text { HEMPBA }\end{array}$ & $\begin{array}{l}\text { Wastewater } \\
\text { treated by } \\
\text { HEMPM }\end{array}$ & $\begin{array}{l}\text { Wastewater } \\
\text { treated by } \\
\text { HEMPCD }\end{array}$ \\
\hline chloroform & 233 (104) & $85(26)$ & $106(34)$ & $50(43)$ & $3.6(2.8)$ \\
\hline 1,2-dichloroethane & $3.22(3.14)$ & $0.95(0.39)$ & $2.83(2.77)$ & $1.24(0.88)$ & $<0.5$ \\
\hline dichloromethane & $6.3(1.15)$ & $0.89(0.49)$ & $1.84(1.29)$ & $2.32(2.42)$ & $1.67(2.89)$ \\
\hline tetrachloroethylene & $9(14.7)$ & $7(11.2)$ & $7.33(11.8)$ & $1.7(2.08)$ & $<0.5$ \\
\hline trichloroethylene & $1.07(0.5)$ & $<0.5$ & $<0.5$ & $<0.5$ & $<0.5$ \\
\hline nonylphenol & $222(138)$ & $163(109)$ & $175(115)$ & $60(28)$ & $4.7(0.8)$ \\
\hline 4-tert-octylphenol & $1.67(2.02)$ & $<0.5$ & $1.52(1.76)$ & $0.7(0.35)$ & $<0.5$ \\
\hline 4-tert-butylphenol & $1.77(2.89)$ & $1.06(1.67)$ & $1.73(2.83)$ & $0.73(1.1)$ & $<0.5$ \\
\hline $\begin{array}{c}\text { nonylphenol } \\
\text { monoethoxylate }\end{array}$ & $0.29(0.16)$ & $0.13(0.07)$ & $0.26(0.15)$ & $0.12(0.07)$ & $<0.1$ \\
\hline nonylphenol diethoxylate & $1.87(1.64)$ & $1.28(0.85)$ & $0.85(1.77)$ & $1.58(0.53)$ & $<0.1$ \\
\hline 2-methylphenol & $0.06(0.01)$ & $0.05(0)$ & $<0.05$ & $<0.05$ & $<0.05$ \\
\hline 3-methylphenol & $0.12(0.07)$ & $0.07(0.03)$ & $0.09(0.07)$ & $0.07(0.03)$ & $<0.05$ \\
\hline 4-methylphenol & $0.06(0.01)$ & $0.05(0)$ & $0.06(0.01)$ & $<0.05$ & $<0.05$ \\
\hline 2-chlorophenol & $0.23(0.24)$ & $0.12(0.12)$ & $0.23(0.24)$ & $0.12(0.12)$ & $<0.05$ \\
\hline 4-chlorophenol & $0.37(0.55)$ & $0.36(0.54)$ & $0.37(0.55)$ & $0.25(0.35)$ & $<0.05$ \\
\hline 2,4-dichlorophenol & $0.72(0.6)$ & $0.46(0.48)$ & $0.68(0.55)$ & $0.36(0.42)$ & $<0.05$ \\
\hline 2,3-dichlorophenol & $0.06(0.02)$ & $0.05(0)$ & $0.06(0.02)$ & $<0.05$ & $<0.05$ \\
\hline 3,4-chlorophenol & $0.08(0.06)$ & $0.07(0.03)$ & $0.08(0.06)$ & $0.07(0.03)$ & $<0.05$ \\
\hline 2,4,6-trichlorophenol & $2.75(0.8)$ & $1.98(0.58)$ & $2.4(0.52)$ & $1.05(0.71)$ & $<0.25$ \\
\hline 1,2-dichlorobenzene & $81.6(28.8)$ & $61.4(19.9)$ & $72.9(25.7)$ & $41.9(17.3)$ & $2.37(2.51)$ \\
\hline 4-chloro-3-methylphenol & $0.12(0.144)$ & $<0.05$ & $0.14(0.16)$ & $0.11(0.1)$ & $<0.05$ \\
\hline toluene & $14.7(12.3)$ & $8(7)$ & $12.7(10.7)$ & $5(5.3)$ & $<1$ \\
\hline anthracene & $0.12(0.1)$ & $0.07(0.11)$ & $0.01(0)$ & $0.01(0)$ & $<0.01$ \\
\hline phenanthrene & $0.19(0.02)$ & $0.08(0.06)$ & $0.09(0.07)$ & $0.01(0)$ & $<0.01$ \\
\hline naphthalene & $1.05(0.52)$ & $0.49(0.56)$ & $0.49(0.5)$ & $0.29(0.3)$ & $<0.01$ \\
\hline fluoranthene & $0.133(0.005)$ & $0.08(0.06)$ & $0.09(0.07)$ & $<0.01$ & $<0.01$ \\
\hline pyrene & $0.013(0.005)$ & $<0.01$ & $<0.01$ & $<0.01$ & $<0.01$ \\
\hline ethylbenzene & $0.49(0.83)$ & $0.23(0.38)$ & $0.37(0.63)$ & $0.41(0.69)$ & $0.29(0.48)$ \\
\hline isopropylbenzene & $0.87(0.32)$ & $0.8(0.26)$ & $0.8(0.26)$ & $0.55(0.09)$ & $0.37(0.22)$ \\
\hline
\end{tabular}




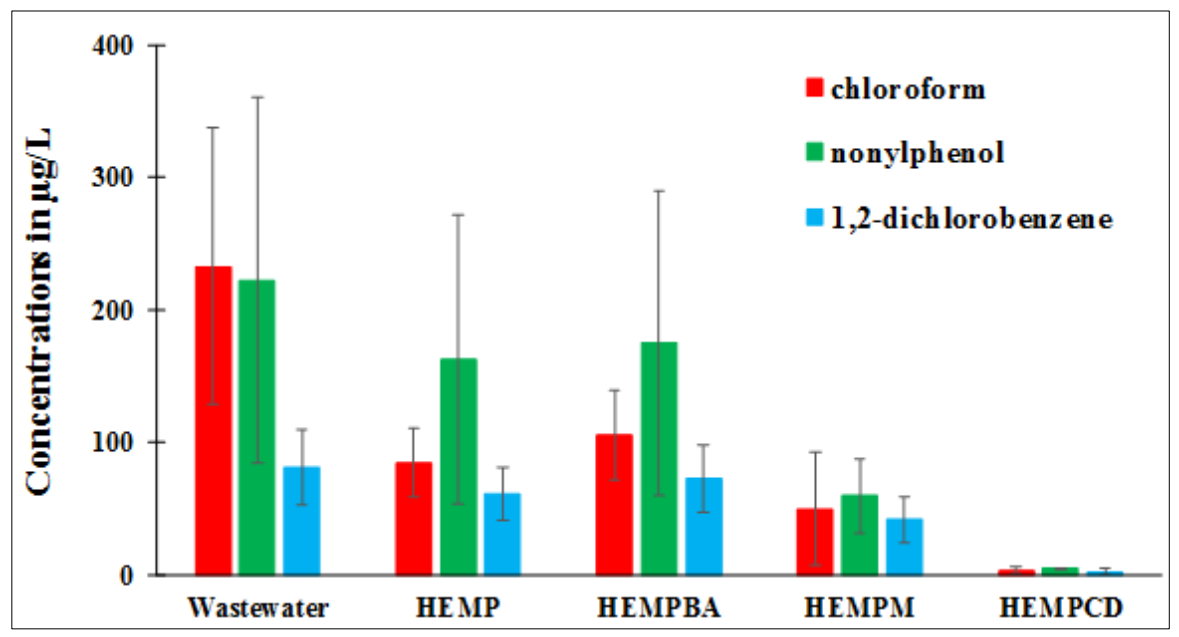

Figure 3. Concentrations (in $\mu \mathrm{g} / \mathrm{L}$ ) of chloroform, nonylphenol and 1,2-dichlorobenzene for the three wastewaters before (raw wastewater) and after hemp treatment (HEMP, HEMPBA, HEMPM and HEMPCD)

\subsection{Effect of hemp treatment on water toxicity}

From a chemical point of view, treating the wastewaters has helped not only to reduce the concentration of contaminants but also to completely eliminated part of them (concentration under QL). The total number of substances identified and quantified before and after hemp treatment in samples is shown in Tables 6 and 7. Before treatment, the number of contaminants were 45, 53 and 49 for W1, W2 and W3, respectively. After hemp treatment, the number of substances decreased (Table 6), whatever the wastewater and the material used. Nevertheless, notable differences were observed. HEMPBA was particularly effective in complexing metals (e.g. for W1, the number of metals were 14 and 5 before and after treatment, respectively), while the best performance for organic substances was obtained with HEMPCD (Tables 6 and 7). To confirm this positive impact and to evaluate the environmental benefits of the chemical treatment on water toxicity, bioassays were performed. To this end, measurements of inhibition of D. magna mobility and of germination rate of L. sativa seeds were also carried out on wastewater after hemp treatment, and compared with those obtained before treatment. The results given in Table 11 compare the potential toxicity of wastewaters on bio-indicator D. magna with that of the same effluents after adsorption on the proposed four materials. After hemp treatment, the impact on $D$. magna was reduced, as indicated by higher EC values, whatever the material used. For instance, daphnid EC50 values were $0.7 \%$ for $\mathrm{W} 1$ and $46.3 \%, 79.3 \%, 84.3 \%$ and $>90 \%$ for the same wastewater treated by HEMP, HEMPBA, HEMPM and HEMPCD, respectively. Decreasing concentrations of contaminants in wastewater W1 led to a significant reduction of their impact on daphnid immobility. For the three wastewaters, the treatment by HEMPCD gave better results since exposure to the wastewaters for $24 \mathrm{~h}$ did not cause immobilization (EC50 > 90\%, Table 11).

Table 11. Toxicity values expressed by EC50 in percentage of wastewater for Daphnia magna for three samples before and after hemp treatment $(\mathrm{n}=1)$

\begin{tabular}{|c|c|c|c|c|c|}
\hline Wastewater & $\begin{array}{c}\text { Wastewater } \\
\text { before } \\
\text { treatment }\end{array}$ & $\begin{array}{c}\text { Wastewater } \\
\text { treated by } \\
\text { HEMP }\end{array}$ & $\begin{array}{c}\text { Wastewater } \\
\text { treated by } \\
\text { HEMPBA }\end{array}$ & $\begin{array}{c}\text { Wastewater } \\
\text { treated by } \\
\text { HEMPM }\end{array}$ & $\begin{array}{c}\text { Wastewater } \\
\text { treated by } \\
\text { HEMPCD }\end{array}$ \\
\hline W1 & 0.7 & 46.3 & 79.3 & 84.3 & $>90$ \\
\hline W2 & 3.1 & 55.8 & 77.3 & 82.3 & $>90$ \\
\hline W3 & 2.7 & 54.3 & 75.9 & 81 & $>90$ \\
\hline
\end{tabular}


A bioassay based on the germination rate of L. sativa seeds was also performed on samples after hemp treatment. Figure 4 compares the germination success of seeds soaked in wastewaters and the same effluents treated by hemp. The average germination rate values $(n=3)$ were: $95 \% \pm 5$ for the controls, $15.5 \% \pm 4.8$ for wastewaters, $62.9 \% \pm 5.7$ after HEMP treatment, $89.5 \% \pm 2.2$ after HEMPBA treatment, $83.4 \% \pm 1.7$ after HEMPM treatment, and 94.7\% \pm 1.4 after HEMPCD treatment. All the materials including HEMP exhibit good improvement of germination rates. After HEMPBA and HEMPCD treatment, the impact on lettuce germination is considerably reduced, suggesting contaminant removal by these two materials obviously decreases the water toxicity.

The two biological tests used in this work made it possible to show the interest of a better chemical efficiency from the point of view of the reduction of contaminants on the toxicity of water. In addition, they have demonstrated that the benefits of this efficiency can lead to an environmental gain, i.e. less toxic industrial effluent when released into the environment.

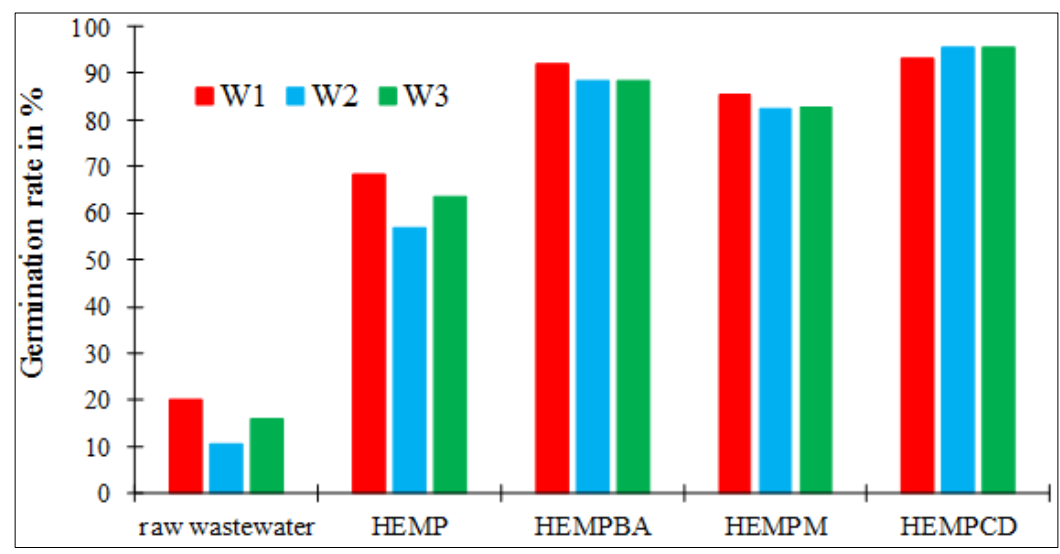

Figure 4. Variations in Lactuca sativa seed germination

$(n=3)$ for the three wastewaters before (raw wastewater)

and after hemp treatment (HEMP, HEMPBA, HEMPM and HEMPCD)

\section{Conclusions}

In this study, added value was added to hemp-based materials through environmentally friendly chemical modification. This work demonstrated that adsorption on these materials in the form of felt could be a practical and effective step to significantly reduce metals and organic substances in polycontaminated industrial wastewaters containing high contaminant loads and, consequently, their toxicity. Of the four materials proposed, hemp simply modified with BTCA had the best absolute performance for metal decontamination. However, only felt coated with hydroxypropyl- $\beta$-cyclodextrin1,2,3,4-butanetetracarboxylic cross-linked polymer was able to effectively remove metals and organics at the same time, highlighting the important role of both the carboxylate groups and cyclodextrin molecules grafted on felt. Bioassays, consisting of measurements of mobility inhibition of Daphnia magna and of the germination rate of Lactuca sativa seeds carried out on wastewaters before and after hemp treatment, confirmed the effectiveness of hemp treatment in dramatically reducing effluent toxicity, especially when the felt coated with hydroxypropyl- $\beta$-cyclodextrin-1,2,3,4-butanetetracarboxylic cross-linked polymer was used. The obtained results in terms of chemical abatement and toxicity mitigation have demonstrated that adsorption onto a nonconventional material could be an interesting treatment step for the detoxification of industrial wastewater. Here, the modified felts were used in batch processes but in future applications they could be used as a bag filter. Also more experiments will be carried out using other real effluents.

Acknowledgments: The authors would like to thank the FEDER (Fonds Européen de Développment Régional) for its financial support (NIRHOFEX Program: "Innovative materials for wastewater treatment", the Université de Franche-Comté for the research grant awarded to Guest Professor C. Bradu, the Région Bourgogne Franche-Comté for the research grant awarded to Guest Researcher C. Cosentino, 
Eurochanvre France (Mr. G. Chanet) for the supply of hemp, and J. Bugnet (Chrono-environnement) and Sarah Girardot (VMC Pêche) for technical assistance.

\section{References}

1. MORIN-CRINI N., CRINI G. Eaux Industrielles Contaminées (in French). PUFC, Besançon, France, 2010.

2. FUERHACKER M. The water framework directive-can we reach the target? Water Sci. Technol. 57, 2008, 9-17.

3. BARROS M., TORRES M., BELLO P., ROCA E., CASARES J. Integrated pollution prevention and control in the surface treatment industries in Galicia (NW Spain). Clean. Tech. Environ. Policy 10, 2008, 175-188.

4. KHALAF M.N. Green polymers and environmental pollution control. Oakville: CRC Press; Apple Academic Press, Inc., 2016.

5. SHARMA S.K., SANGHI R. Advances in water treatment and pollution prevention. Dordrecht: Springer; 2012, $457 \mathrm{p}$.

6. OLIVEIRA L.S., FRANCA A.S. In: Low cost adsorbents from agro-food wastes. Columbus, F., Ed.; Food Science and Technology: New Research. New-York: Nova Publishers; 2008, pp. 1-39.

7. LI C. B., HEIN S. WANG K. Biosorption of chitin and chitosan. Mat. Sci. Technol. 24, 2008, 10881099.

8. WANG J.L., CHEN C. Biosorbents for heavy metals and their future. Biotechnol. Adv. 27, 2009, 195226.

9. DULMAN V., CUCU-MAN S.M. Wood sawdust, tree bark and wood chips: Waste lignocellulosic materials for dye removal. In: Crini, G., and Badot, P. M. eds. Sorption processes and pollution. Besançon: Presses Universitaires de Franche-Comté; 2010, Chapter 9, pp. 233-269.

10. HUBBE M.A., HASAN S. H., DUCOSTE J. J. Cellulosic substrates for removal of pollutants from aqueous systems: a review. Bioresources 6, 2011, 2161-2914.

11. KYZAS G.Z., KOSTOGLOU M. Green adsorbents for wastewaters: a critical review. Materials 7 , 2014, 333-364.

12. RENU B., AGARWAL M., SINGH K. Heavy metal removal from wastewater using various adsorbents: a review. J. Water Reuse Des. 7, 2017, 87-419.

13. RUELA-LEYVA J.P., CONTRERAS-ANDRADE I., SARMIENTO-SÁNCHEZ J.I., LICEACLAVERÍE A., JIMÉNEZ-LAM S.A., CRISTERNA-MADRIGAL Y.G., PICOS-CORRALES L.A. (2017) The effectiveness of Moringa oleifera seed flour and chitosan as coagulant-flocculants for water treatment. Clean Soil Air Water 45, 2017, 1600339.

14. TOFAN L., PĂDURARU C. Sorption studies of $\mathrm{Ag}(\mathrm{I}), \mathrm{Cd}(\mathrm{II})$ and $\mathrm{Pb}(\mathrm{II})$ ions on sulphydryl hemp fibres. Croatica Chem. Acta 77, 2004, 581-586.

15. PĂDURARU C., TOFAN L. Investigations on the possibility of natural hemp fibres use for $\mathrm{Zn}$ (II) removal from wastewaters. Environ. Eng. Manage. J. 7, 2008, 687-693.

16. TOFAN L., TEODOSIU C., PĂDURARU C., WENKERT R. Cobalt(II) removal from aqueous solutions by natural hemp fibres: batch and fixed-bed columns studies. Appl. Surf. Sci. 285P, 2013, 3339.

17. TOFAN L., PĂDURARU C., TEODOSIU C., TOMA O. Fixed bed columns study on the removal of chromium (III) ions from aqueous solutions by hemp fibres with improved sorption performance. Cellulose Chem. Technol. 49, 2015, 219-229.

18. TOFAN L., PĂDURARU C., TOMA O. Zinc remediation of aqueous solutions by natural hemp fibres: batch desorption/regeneration study. Des. Water Treatment. 57, 2016, 12644-12652.

19. PEJIĆ B. M., VUKČEVIĆ M. V., KOSTIĆ M., SKUNDRIC P. Biosorption of heavy metal ions from aqueous solutions by short hemp fibres: Effect of chemical composition. J. Hazard. Mat. 164, 2009, 146-153. 
20.KOSTIĆ M., PEJIĆ B.M., ASANOVIC K.A., ALEKSIC V.M., SKUNDRIC P.D. Effect of hemicelluloses and lignin on the sorption and electric properties of hemp fibres. Ind. Crops Products 32, 2010, 169-174.

21.PEJIĆ B.M., VUKČEVIĆ M.V., PAJIĆ-LIJAKOVIĆ I., LAUŠEVIĆ M.D., KOSTIĆ M. Mathematical modeling of heavy metal ions $\left(\mathrm{Cd}^{2+}, \mathrm{Zn}^{2+}\right.$ and $\left.\mathrm{Pb}^{2+}\right)$ biosorption by chemically modified short hemp fibres. Chem. Eng. J. 2011, 72, 354-360.

22.VUKČEVIĆ M. V., LAUŠEVIĆ M., PAJIĆ-LIJAKOVIĆ I., KOSTIĆ M. Influence of chemically modified short hemp fiber structure on biosorption process of $\mathrm{Zn}^{2+}$ ions from waste water. Fibers and Polymers 15, 2014, 687-697.

23. REZIĆ I. Cellulosic fibres - Biosorptive materials and indicators of heavy metal pollution. Microchem. J. 107, 2013, 63-69.

24. KYZAS G., TERZOPOULOU Z., NIKOLAIDIS V., ALEXOPOULOU E., BIKIARIS D.N. Lowcost hemp biomaterials for nickel ions removal from aqueous solutions. J. Molecular Liq. 209, 2015, 209-218.

25.BUGNET J., MORIN-CRINI N., COSENTINO C., CHANET G., Winterton P., CRINI G. Hemp decontamination of poly-metallic aqueous solutions. Environ. Eng. Manage. J. 16, 2017, 535-542.

26. LOIACONO S., MORIN-CRINI N., COSENTINO C., TORRI G., CHANET G., Winterton P., CRINI G. Simultaneous removal of $\mathrm{Cd}, \mathrm{Co}, \mathrm{Cu}, \mathrm{Mn}, \mathrm{Ni}$ and $\mathrm{Zn}$ from synthetic solutions on a hempbased felt: Experimental design. J. Appl. Polym. Sci. 134, 2017, 44422.

27. LOIACONO S., CRINI G., MARTEL B., CHANET G., COSENTINO C., Raschetti M., PLACET V., TORRI G., MORIN-CRINI G. Simultaneous removal of $\mathrm{Cd}, \mathrm{Co}, \mathrm{Cu}, \mathrm{Mn}, \mathrm{Ni}$ and $\mathrm{Zn}$ from synthetic solutions on a hemp-based felt. 2: Chemical modification. J. Appl. Polym. Sci. 134, 2017, 45138.

28. LOIACONO S., CRINI G., CHANET G., RASCHETTI M., PLACET V., MORIN-CRINI N. Metals in aqueous solutions and real effluents: biosorption behavior of a hemp-based felt. J. Chem. Technol. Biotechnol. 93, 2018, 592-2601.

29. LOIACONO S., MORIN-CRINI N., MARTEL B., CHANET G., BRADU C., TORRI G., CRINI G. Zinc, copper, and manganese complexation by hemp: chemical abatement and ecotoxicological impact. Environ. Risques Santé 17, 2018, 240-252.

30.MORIN-CRINI N., LOIACONO S., PLACET V., TORRI G., BRADU C., KOSTIĆ M., COSENTINO C., CHANET, G., MARTEL, B., LICHTFOUSE E., CRINI, G. Hemp-based adsorbents for sequestration of metals: A review. Environ. Chem. Lett. 17, 32019, 93-408.

31.MORIN-CRINI N., STAELENS J. N., LOIACONO S., MARTEL B., CHANET G., CRINI G. Simultaneous removal of $\mathrm{Cd}, \mathrm{Co}, \mathrm{Cu}, \mathrm{Mn}, \mathrm{Ni}$ and $\mathrm{Zn}$ from synthetic solutions on a hemp-based felt. III. Real discharge waters. J. Appl. Polym. Sci. 137, 2020, 48823.

32.MARTEL B., WELTROWSKI M., RUFFIN D., MORCELLET M. Polycarboxylic acids as crosslinking agents for grafting cyclodextrins onto cotton and wool fabrics: study of the process parameters. J. Appl. Polym. Sci. 83, 2002, 1449-1456.

33.DUCOROY L., MARTEL B., BACQUET M., MORCELLET M. Cation exchange finishing of nonwoven polyester with polycarboxylic acids and cyclodextrins. J. Appl. Polym. Sci. 103, 2007, 37303738 .

34.DUCOROY L., BACQUET M., MARTEL B., MORCELLET M. Removal of heavy metals from aqueous media by cation exchange nonwoven PET coated with $\beta$-cyclodextrin-polycarboxylic moieties. React. Funct. Polym. 68, 52008, 94-600.

35.DRUART C., MORIN-CRINI N., EUVRARD E., CRINI G. Chemical and ecotoxicological monitoring of discharge water from a metal-finishing factory. Environ. Process. 3, 2016, 59-72.

36.MORIN-CRINI N., DRUART C., GAVOILLE S., LAGARRIGUE C., CRINI G. Analytical monitoring of the chemicals present in the discharge water generated by the surface treatment industry. J. Environ. Protection 4, 2013, 53-60. 
37.SANCEY B., CHARLES J., TRUNFIO G., BADOT P.M., JACQUOT M., HUTINET X., GAVOILLE S., CRINI G. Effects of additional sorption treatment of industrial water discharge by crosslinked starch. Ind. Eng. Chem. Res. 50, 2011, 1749-1756.

38.CHARLES J., SANCEY B., MORIN-CRINI N., BADOT P.M., DEGIORGI F., TRUNFIO G., CRINI G. Evaluation of the phytotoxicity of polycontaminated industrial effluents using the lettuce plant (Lactuca sativa) as a bioindicator. Ecotoxicol. Environ. Safety 74, 2011, 2057-2064.

39. VOLESKY B., HOLAN Z. R. Biosorption of heavy metals. Biotechnol Prog. 11, 1995, 235-250.

40. VIJAYARAGHAVAN K., BALASUBRAMANIAN R. Is biosorption suitable for decontamination of metal-bearing wastewaters? A critical review on the state-of-the-art of biosorption processes and futures directions. J. Environ. Manag. 160, 22015, 83-296.

41.VANDENBOSSCHE M., JIMENEZ M., CASETTA M., TRAISNEL, M. Remediation of heavy metals in wastewaters by biomolecules - A review. Critical Rev. Environ. Sci. Technol. 45, 2015, 16441704.

42. PEARSON R.G. Hard and soft acids and bases. J. Am. Chem. Soc. 85, 1963, 3533-3539.

43. PEARSON R.G. Hard and soft acids and bases, HSAB, part 1: Fundamental principles. J. Chem. Educ. 45, 1968, 581.

44. PEARSON R.G. Hard and soft acids and bases, HSAB, part II: underlying theories. J. Chem. Educ. 45, 1968, 643.

45. PEARSON R.G. Hard and soft acids and bases. Surv. Prog. Chem. 5, 1969, 1-52.

46. NIEBOER E., RIDCHARSON D.H.S. The replacement of the nondescript term 'heavy metals' by a biologically and chemically significant classification of metal. Environ. Pollut. Series B 1, 1980, 3-26. 47. EUVRARD E., MORIN-CRINI N., DRUART C., BUGNET J., MARTEL B., COSENTINO C., MOUTARLIER V., CRINI G. Cross-linked cyclodextrin-based material for treatment of metals and organic substances present in industrial discharge waters. Beilstein J. Org. Chem. 12, 2016, 1826-1838.

$\overline{\text { Manuscript received: } 1.10 .2020}$ 